\title{
The Effect of Road Transport Network on Agricultural Produce Marketing in Giwa Local Government Area of Kaduna State \\ By \\ FOIN DAVID NCHOUJI
}

\begin{abstract}
The study focused on the effects of road transport network on agricultural produce marketing in Giwa Local Government Area of Kaduna state. It took a critical look at the development of road network connectivity and the development of markets with a view to understand the level to which this network components affected agricultural produce marketing over a period of four decades (1965 - 2007). The result showed that internal and external trade in Giwa is characterized by relatively well developed economic networks epitomized in its market places and other retail institutions. In a predominately rural economy like of Giwa, market institutions are important nodes of exchange of goods/services and agricultural produce. Most of the periodic markets are located on roads sides or nucleated settlements with a road link. It also showed that the development of markets depended on development of road network. It further showed that the scheduling of periodic market is integrated with their locational spacing with a closed relationship between market provision, road network and population density. New reasons are advanced in an attempt to explain periodic marketing in terms of temporal variations in effective demand. Hypotheses are derived to test its validity. The empirical results showed that development of market depends on road network which synchronized the needs and objectives of the rural produce/services and substantial improvements in the system can be emphasized.
\end{abstract}

\begin{abstract}
Introduction
Transport is indispensable to economic development especially in a developing country like Nigeria. this is because transport is essential to execution of daily economic and social activities in any given area. (Aloba, 1975). Thus, at any given stage of economic development, a country or region required a certain level of transport facilities in order to maximize its resource potentialities (Amadi, 1987).
\end{abstract}

Transport act as an catalyst for the movement of people and agricultural produce and as a subsystem of the economy. It sustained the other components by making them interact. It is seen as a promoter of accessibility. The capacity and connectivity of a network is very important in regional and national development.

In view of the tremendous importance of transport in the lives of millions of ordinary people living in rural areas, a high priority of transport policy should be to extend and improve rural transport within the reach of most people and increase overall mobility for the average man and woman in rural areas. Increased connectivity of road network cheapens the costs of transport to the market and thereby bring addition buyers and sellers in contact to one another with the consequence of increase in elastically of demand and supply goods and services. This there helps to minimize shortage of food products and raw materials.
The term "market" and the equivalent terms in Hausa "Kasuwa" have many connotations. Therefore, authors from various disciplines have different meaning to the word. Whelhan (1972) defines market as an institution for exchange for goods and services. This is the line with Holden el al Uku's definition that "a market is an authorized public concourse of buyers and sellers of community meeting an appointed time. (Holden el al 1969). There are many types of markets. These can be group in terms several variable like scale of transaction, types of commodity sold, periodicity and time. The most valid and useful classification in Nigeria and for the study area is the one based on periodicity of operation usually and in rural, semi-urban and urban areas.

Markets are necessary because people are not capable of producing all the things they need for survival (Daramola, 1999).Therefore, marketing is an integral part of the production process. The storing, transporting and delivery are basic parts of marketing. Each function that occurs in marketing is between the time the farmer first offers his produce foe sale and when the final purchased is made.

\section{Theoretical Framework}

An attempt to compromise between formal structure of perfect competitive market in economic theory and empirical observations of organization experience in the imperfect markets of the real world had led to the adaptation for the 
structure of agriculture marketing investigations (Bain, 1959, Bateman 1976). Structures and conducts of markets are influenced by "basic conditions like location, price elasticity of demand for product, laws and government policies within a fire. (Siharer, 1970). Market performance refers to the economic results of structures, conduct and how well it performance in terms of efficiency and progressiveness given its technical environment (Bain, 1959).

The results can be measured in terms of price, product, services, volume, quality, innovations and technical progress. More commonly, time series and time data are used to throw light in degree of competition in marketing systems.

However, the government and the planner in most developing countries are beginning to acknowledge the importance of an efficient marketing facilities to economic development. Indachaba et al (1991) noted that "market infrastructures holds the key to sustained agricultural production and hence economic development". An improvement in efficiency in food distribution can spell relatively large gains in real income for expenditure on other commodities and at the same time provide incentives to the farmers in the market system which will contribute to the objective of agriculture and total economic development through providing a more optimal allocation of society's resource.

Markets can be classified based on periods of operations (whether daily or occurring at regular intervals of operations, night or day). However, there seems to be no universally acceptable definition of term marketing (Kusawanchi). Individual variety of opinions exists concerning the subject. baker (1981) defined marketing as the process of making goods available for consumption. This implies that market covers all business functions, including production in its broadest decisions. Thus it can be argued that in farming, such decisions as variety of crops to grow, or the breed of animals to keep are marketing decisions. According to Kohl's (1968) marketing is the performance of all business activities involve in the flow of goods and services from the point of initial agricultural production until they are in the hand of ultimate consumer. However, the primary role of marketing system is to add to form, place, time and possession utility, so that the subjective satisfaction of the consumer is maximized and return to the producer is assured. If agricultural marketing consist of these business activities that go into getting a product into the hands of the consumer and at the same time satisfies the interest of the farmer, then marketing efficiency can be defined as the movement of goods and services (agricultural products) to consumer in the right time and place with lowest possible marketing cost consistent with the interest of the producer.

Periodic markets places form an integral part of the spatial economic system of rural communities in Hausa land. Although the expansion of urban demand for foodstuff has stimulated the direct sale of produce to urban consumers by rural- producers, the vast majority of agricultural produces still entered the market system through the local periodic markets (Gana, 1970).

The provision of adequate and good transport network in rural areas will go to very long may to improve the lives of the natural majority in Nigeria. cheap transport fuses markets, bring additional buyers and sellers thereby increasing demand and supply. This can make possible the position of the farmer to raise above subsistence level and reduce poverty, unemployment and inadequate incomes.

\section{Population and Methods Adopts}

The study was conducted in Giwa local Government Area which is located on latitude $10^{\prime} 50 \mathrm{~W}$ and $11^{\prime} 25 \mathrm{~N}$ and longitude $7{ }^{\prime} 15 \mathrm{E}$ and $7{ }^{\prime} 28 \mathrm{~N}$. it is situated in the Northern Guinea savanna. The Local government bounded in the North by Funtua local Government Area of Katsina state to the West by Birin Gwari, to the East by Igabi and Faskari Local Government Areas. And Zaria local Government area According to the 2006 census report, there are 47 villages and a total population of 286427(NPC, 2006).

Agriculture is the major source of livehood in the area and farming activities are undertaken by the male folk. The major crops grown are maize, guinea corn, beans, rice, groundnut, soya beans, pepper and millet. The crops are produce for sale and as well as local consumption. However, some of the crops were produce mostly entirely for sale with very little consumed locally. 
The primary data were obtained using two structured set of questionnaires. The research and field assistants used to collect the data include farmers, grains seller, traders and sales agents. A total of 353 farmers were randomly selected among 12 villages. The study was divided into three, based on the present three districts that made up the local government area. The districts are Giwa, Fatika and Shika. To ensure a fair and even distribution of the villages, the random table was used. The analytic tools used for the study are, simple descriptive statistics which were employed to have a summary description of the data collected. This involve the use of central tendency such as percentages, means and frequency distribution. Chi-square analysis was used to determine relationship between the road transport network and agricultural produce marketing. Thus the formula used was

$E X^{2} \frac{(\mathrm{O}-\mathrm{E})^{2}}{\mathrm{E}}$

Where $\mathrm{X}^{2}$ is the chi-square symbol

$\mathrm{O}=$ observed number of links

$\mathrm{E}=$ Expected Number markets

$\mathrm{D}=\quad$ Number of degree of freedom

$(\mathrm{r}-1)(\mathrm{c}-1)=2$

In analyzing the transportation network, abstraction represented by series of vertices and edges were used.

The degree of connection between all vertices in the analysis is defined as the connectivity of the network. (Hagget, 1969) the concept of connectivity is most meaningful when a given network is either compared with other network or its growth is viewed through time. In order to compared the structural complexity of road network in the study area, a three time s period, 1965, 1990 and 2007 measured were used. This was to help describe the network connectivity. The three graphic theoretic measures used in analyzing the road network connectivity are gamma, beta and alpha indices.

\section{Result and Discussion}

The variable analyzed in this study include age, education, status, types of farming practices, road network connectivity and development of markets.
Table 1: Socio-economic characteristics of the farmers and types of farming Practices

\begin{tabular}{|l|l|l|}
\hline Variable & $\begin{array}{l}\text { No of } \\
\text { respondents }\end{array}$ & Percentage \\
\hline Ages in years & 86 & 25 \\
$21-30$ & 113 & 32 \\
$31-40$ & 80 & 22 \\
$41-50$ & 57 & 16 \\
$51-60$ & 17 & 5 \\
61 and above & 21 & 6 \\
\hline Level Education & & 11 \\
Tertiary & 39 & 19 \\
Secondary & 68 & 64 \\
Primary & 225 & \\
No & & 47 \\
formal/Arabic & 167 & 22 \\
\hline $\begin{array}{l}\text { Types } \\
\text { farming }\end{array}$ & 77 & 31 \\
Rainfed & 109 & \\
Irrigation & & \\
Both & & \\
\hline
\end{tabular}

Source: field survey, 2007

The farmers can be grouped into three major groups constituting $78 \%$. The young farmers in the age bracket of $21-30(25 \%)$ middle age farmers $31-40(32 \%)$ and 41-50(22\%). While 51years and above constitute the old farmers. The study also showed that $98 \%$ of the respondents were males. This suggest that the ethnic composition (Hausa/Fulani) of the area and religious values plays a significant role in farming activities in the area. The culture and religious values forbids women and only permit males to go out and farm.

The literacy level of the farmers is very low with over $64 \%$ having no formal education. Arabic and Islamic education is the major form of education in the area. This is not surprising because this area had been under Islamic influence for centuries. Rain fed agricultural is the predominate type of farming practice of the area. 
Table 2: distribution of sample respondents to the numbering of road leading into and out of the villages

\begin{tabular}{|l|l|l|}
\hline $\begin{array}{l}\text { No of } \\
\text { Roads }\end{array}$ & Respondents & Percentage \\
\hline 1 & 108 & 30 \\
\hline 2 & 98 & 28 \\
\hline 3 & 17 & 5 \\
\hline 4 & 16 & 5 \\
\hline 5 & 2 & 0.6 \\
\hline 6 & 1 & 02 \\
\hline No road & 111 & 31.2 \\
\hline Source:
\end{tabular}

Source: field survey, 2007

Most of the villages have few roads leading into and out of item. The survey revealed that most roads were constructed through communal effort while local and state government participation in roads construction activities is minimal.

Table 3: The no of villages link and establishment of markets from 1965.

\begin{tabular}{|l|l|l|l|l|l|}
\hline $\begin{array}{l}\text { S/N } \\
\text { o }\end{array}$ & $\begin{array}{l}\text { No. } \\
\text { of } \\
\text { link } \\
\text { s }\end{array}$ & $\begin{array}{l}\text { Village } \\
\text { s }\end{array}$ & Beta & $\begin{array}{l}\text { Gamm } \\
\text { a }\end{array}$ & $\begin{array}{l}\text { Market } \\
\text { s }\end{array}$ \\
\hline $\begin{array}{l}199 \\
5\end{array}$ & 3 & 47 & $\begin{array}{l}6.3 \\
\%\end{array}$ & $2.2 \%$ & 1 \\
\hline $\begin{array}{l}199 \\
0\end{array}$ & 19 & 47 & $40 \%$ & $14 \%$ & 3 \\
\hline $\begin{array}{l}200 \\
7\end{array}$ & 37 & 47 & $79 \%$ & $27 \%$ & 7 \\
\hline
\end{tabular}

Source : Field survey 2007

The Beta index is used in this study as a measure of accessibility and roads network connectivity in Giwa local Government Area over a three times period 1965, 1990 and 2007. it was used as the measure of analyzing the accessibility and to compare the network connectivity at different times in space $\mathrm{B}-\mathrm{e} / \mathrm{v}$ e - edges v- verties.

The Beta index indicate that any network less than one is a partially accessible or connected. The Beta index indicates that in 1965 only 0.063 $(6.3 \%)$ of the total numbers of villages were linked. This means that the area was only partially connected. In 1990, the numbers of villages connected has increased to $40.0 \%$ and by 200737 villages representing $79 \%$ had been linked. The connectivity level (79\%) revealed by Beta is indicative of the road in Giwa Local Government Area. However, the connectivity level is only said to be true if all the road are all season roads. In Giwa Local Government Area, over $50 \%$ the roads are usually out of use during the raining season (foin,2007). The Gamma index, which shows the total road network permits direct movement among various nodes in the area was found to have risen from $2.2 \%$ to $16.2 \%$ from 1965 to 2007 . By all standard this connectivity is low (Kansky, 1963). This suggest that Giwa local Government Area is not properly connected or linked. The Alpha index is a ratio based on the number of circuits in the network in 1965. However, by 1990 most of the villages were not still linked. The alpha index will therefore not be applied.

Table 4: Markets, years of establishment and periodicity.

\begin{tabular}{|l|l|l|}
\hline Market & $\begin{array}{l}\text { Year } \\
\text { established }\end{array}$ & Periodicity \\
\hline Giwa & 1955 & 2 \\
\hline Shika & 1975 & 2 \\
\hline Galadimawa & 1981 & 2 \\
\hline Kidanday & 1991 & 1 \\
\hline Kasuwan 'D' AA & 1993 & 2 \\
\hline Kauru kauru & 1995 & 2 \\
\hline Kaye & 1996 & 2 \\
\hline
\end{tabular}

Source: field survey 2007

Table 3 and 4 show that the development of market is depends on the development of road network. The second market was established 20 years after the first (Giwa) in 1955. As more villages were linked up, 6 additional marketing were established within a period of 5 years. Between 1965 and 1990 four markets were established between 1990 and 2001. This is a shorter period between 1965 and 1990. This shows that as road density increase density increase from 1990. This shows that as road network density increase from 1990 three additional markets were established to increase marketing activities of Agricultural produce. 
Table 5: Distribution of sample respondents according to distance covered to market and were produce were sold.

\begin{tabular}{|l|l|l|}
\hline Distance to market & Respondents & Percentage \\
\hline Less than $10 \mathrm{Km}$ & 120 & 34 \\
\hline $11-20 \mathrm{Km}$ & 115 & 32 \\
\hline $21-30 \mathrm{Km}$ & 95 & 27 \\
\hline $31-40 \mathrm{Km}$ & 14 & 4 \\
\hline 41 above & 9 & 3 \\
\hline $\begin{array}{l}\text { Where Produce } \\
\text { Was Sold }\end{array}$ & & \\
\hline Market & 248 & 70 \\
\hline Local shop & 13 & 4 \\
\hline Home & 67 & 19 \\
\hline Other places & 25 & 7 \\
\hline
\end{tabular}

Source: field survey 2007

A majority of the farmers cover distance of up to $10 \mathrm{~km}$ from their homes to the nearest market to them. This suggested that the intensity of land use turn to decrease with increasing distance from major roads to the market. Similarly, the markets decrease as distance increase in relative terms. A majority of the farmer sold their produce in the market $(70 \%)$ while $(30 \%)$ sell in the local shops, homes and other places.

Trekking to the market is less important from home because farmers carry large quantities of their produce to the markets for sale. This could be as a result of a good network of roads available to farmers to move large quantities of their produce to the markets. It could also mean the markets are closer to the farmers.

Table 6: Distribution of sample respondent according to modes of transport used to market.

\begin{tabular}{|l|l|l|}
\hline $\begin{array}{l}\text { Mode of } \\
\text { Distribution }\end{array}$ & Respondents & Percentage \\
\hline Motor car & 225 & 63 \\
\hline Motor cycle & 77 & 22 \\
\hline Bicycle & 18 & 5 \\
\hline Donkey & 24 & 7 \\
\hline $\begin{array}{l}\text { Head } \\
\text { porterage }\end{array}$ & 9 & 3 \\
\hline
\end{tabular}

Source: field survey 2007

Difference modes of transport are used for transporting farm produce, goods and people to different markets in the Local Government Area. About $(63 \%)$ use motor vehicle to the markets. The rest used motor cycles (22\%) bicycles (5\%), head $(3 \%)$ and $7 \%$ still use donkeys as their mode of transportation. Since most farmers use motor vehicle, it seems that most of them have access to good network of roads and could convey large quantities of farm produce to the markets using motor vehicles.

\section{Statistical Test}

The relationship between the road transport and development of markets in the area was examined under the following hypothesis: There is a significant relationship between a good transportation road network and volume of agricultural produce marketing in Giwa Local Government Area.

Table 7: Relationship between the road transport and development of markets in Giwa LGA

\begin{tabular}{|l|l|l|l|l|}
\hline Period & Observed & Expected & Df & $\begin{array}{l}5 \% \text { S.G. } \\
\text { level } \\
\text { Decision }\end{array}$ \\
\hline 1965 & 0.0470 & 0.2329 & & 30.14 \\
\hline 1990 & -0.48648 & 0.07142 & 19 & $\begin{array}{l}\text { Accepted } \\
\text { H0 }\end{array}$ \\
\hline 2007 & 18.5060 & 0.0014 & & $\begin{array}{l}\text { Calculated } \\
\text { value }\end{array}$ \\
\hline & 19.033 & -0.3057 & & 19.339 \\
\hline
\end{tabular}

From the table 7 above, the valve of 30.14 reveals that the table value is greater than the calculated value. Thus this indicated that the null hypothesis, above which stated that there is no significant relationship between road transport network and agricultural produce marketing, is accepted. This indicated that the more developed the road network is the more likely, that all things being equal, the area will attract more markets. By implication, the analysis revealed that if the villages in the Local Government Area are made more accessible by constructing more road links, they are likely to attract more markets. Thus, this will increase marketing activities.

\section{Summary and Conclusion}

Table 3 shows that the development of markets in the study are depend on the development of road network.

From table 1; the literacy level of the farmer is very low, Arabic and Islamic education is the major forms of education in the area. Table 5 shows that majority of the farmer $(70 \%)$ produce and sell their produce in the market. Trekking to 
the market is less important because farmers carry large quantity of their produce to market for sale. This could be as a result of a good network of roads available to the farmer to move large quantities of their produce to the market. Different mode of transportation are used to transport grains, goods and people to various market in their area. A majority of farmers used motorcars to transport their produce for sale at the various markets. Thus, the importance of the road network in the normal life of the economy lie basically in the fact that mobility and accessibility are essential to the achievement of economic as well as social and political. The integration of transport planning with the agricultural sector of the economy is essential to development strategy.

\section{Reference}

Adefolalu, A. H. (1977) The significant of transport in rural development in Environmental and Spatial Factors in Rural Development in Nigeria led Adejeyiebe and G Heileiner, 1977.

Agboola, S. A. (1979) Agricultural Atlas of Nigeria, Oxford University Press, Great Britain.

Adeloba, S, (1980) Some Geographical Aspects of Rural Transport Network in Regional, Phil, Thesis, University of Ife, lle-Ife

Aluko, S, (1980) Developing the Rural Area, in Omu and Makunwa (eds) proceeding of the conference on Integrated Rural Development CENCER; University of Benin.

Amadi, B. C (19987) “ The impact of Road Constructions of Agricultural Development. An empirical study of Anambra State of Nigeria" Agricultural System.

Appleton J.A (1965). A Morphological Approach and Geography of Transport, University of Hall Occasional Paper in Geography.

Azzayba P.J. National Development. Transport Planning and Management Course NITT (1993).
Brain, (1959), Economic Organization of Production. Department of Economic Research paper. No.85.

Baker, (1981) The Distribution Process in Economics. Paper and proceeding Regional, Science Association

Foin D N (2007) The impact of Road Network on the Distribution of Social Amenities in Giwa Local Government. The information manager Vol. 7 (2) 2007.

Foin, D N (2006) The choice and effect of mode on the transportation in the flow of Agricultural Foodstuff in Rural - Urban flow. A case study of Zaria area. Samaru Jornal of information studies (vol1.6 (1\&2) 2006.

Foin D N (2006) marketing of Food grains in selected markets in Zaria Area. (The information manager vol6 (1\&2) 2006

Hay, (1977): The Important of Passenger Transport in Nigeria. "In Holye" BS (ed) London Macmillan.

Hodden and Uku (1985) Studies of Market in West Africa, Ibadan University Press.

Idechaba, F.S (1985) Rural Infrastructure in Nigeria Published for the Department of Rural Development U.I.Ibadan University Press

John Itowe (el ta) (1984) Rural Feeder Roads and Poverty Allevaition. A study prepared for the framework of the World employment Programme.

Kansley, (1963). The Structure of transport network. University of Chicago, Department of Geography Research Paper. No 84.

Kohl's (1968). Marketing efficiency in Agriculture. Department of Agriculture Economics. Univ. Chicago.

Leman; L.S. (1985) Rural Feeder Road and Spatial Development. The current State of Arts and the need of Research, The university Port Harcourt.

Mesely M. (1979); Accessibility, the Rural Challenge, methen and Co-LTD. London.

Sihamer, (1970), Production and Distribution in Economics; Paper and Proceeding Regional association od Science pp. 320-330.

Whelhan, (1972) marketing Channels. Economic Research Paper, Regional Association pp. 101-105 